\title{
Exploring the Relationship between Spiritual Well-Being and Marital Satisfaction among Urban Malays in Malaysia
}

\author{
Suzana Mohd Hoesni, Arena Che Kasim \& Siti Marziah Zakaria
}

To Link this Article: http://dx.doi.org/10.6007/IJARBSS/v11-i4/9664

DOI:10.6007/IJARBSS/v11-i4/9664

Received: 09 February 2021, Revised: 16 March 2021, Accepted: 01 April 2021

Published Online: 24 April 2021

In-Text Citation: (Hoesni et al., 2021)

To Cite this Article: Hoesni, S. M., Kasim, A. C., \& Zakaria, S. M. (2021). Exploring the Relationship between Spiritual Well-Being and Marital Satisfaction among Urban Malays in Malaysia. International Journal of Academic Research in Business and Social Sciences, 11(4), 1261-1273.

\section{Copyright: @ 2021 The Author(s)}

Published by Human Resource Management Academic Research Society (www.hrmars.com)

This article is published under the Creative Commons Attribution (CC BY 4.0) license. Anyone may reproduce, distribute, translate and create derivative works of this article (for both commercial and non-commercial purposes), subject to full attribution to the original publication and authors. The full terms of this license may be seen at: http://creativecommons.org/licences/by/4.0/legalcode

Vol. 11, No. 4, 2021, Pg. 1261 - 1273

Full Terms \& Conditions of access and use can be found at http://hrmars.com/index.php/pages/detail/publication-ethics 


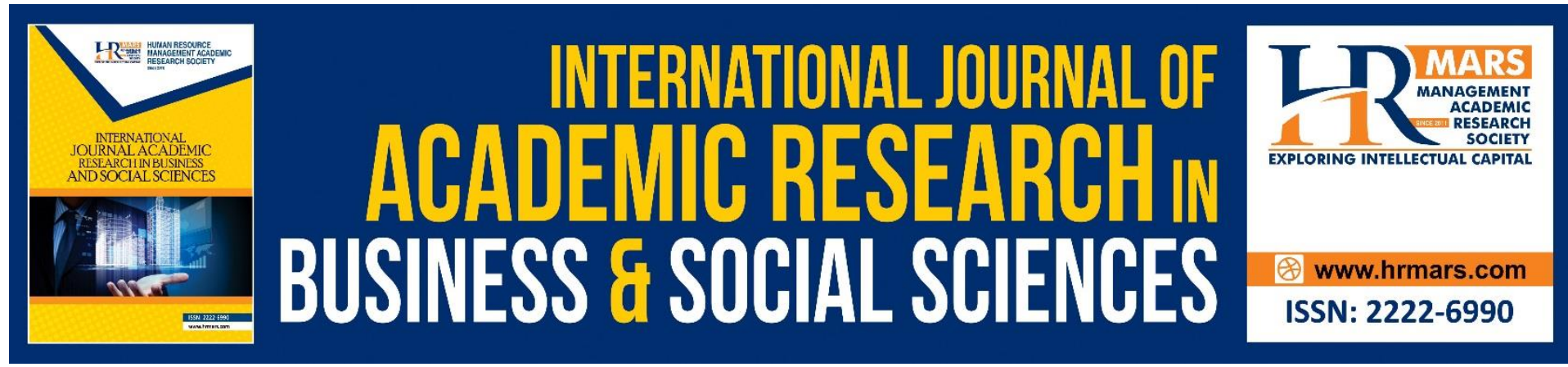

\title{
Exploring the Relationship between Spiritual Well- Being and Marital Satisfaction among Urban Malays in Malaysia
}

\author{
Suzana Mohd Hoesni, Arena Che Kasim \& Siti Marziah Zakaria \\ Center For Research in Psychology and Human Well-Being, Universiti Kebangsaan Malaysia
}

\begin{abstract}
Spiritual well-being is gradually gaining attention by researchers in understanding the psychological process of marital relations. Thus, this study aims to explore the relationship between spiritual well-being and marital satisfaction among married urban Malays. This study is a part of a larger study to identifying psychological aspects within marital relationships. A total of 578 married Malay individuals (male=256, female=322) from the Klang Valley participated voluntarily in this study. Questionnaires consisted of questions related to personal background, spiritual well-being and marital satisfaction were distributed by the enumerators to the respondents. Completed questionnaires were collected by the enumerators and then coded and analyzed using IBM Statistical Package for Social Sciences (SPSS) version 23. Overall, Pearson Correlation Analysis showed that there was a small, positive and significant relationship between spiritual well-being (religiosity) and marital satisfaction $(r=.19 * *, k<0.01)$. In addition, Pearson correlation analysis also showed that there was a medium, positive and significant relationship between spiritual well-being (existential) and marital satisfaction $\left(r=.32^{* *}, k<0.01\right)$. In sum, findings indicated that married individuals with higher spiritual well-being scores were more likely to have high scores in marital satisfaction. This study will have implications for the field of psychology focussing on marital satisfaction. Implication of this study is to the field of psychology focussing on marital satisfaction. Another implication of this study is to the importance of spiritual aspects when helping married individuals and couples. Specifically to helping professions such as counsellors, therapists and social workers in helping individuals and married couples.
\end{abstract}

Keywords: Spiritual Well-Being, Marital Satisfaction, Malay, Urban, Malaysia

\section{Introduction}

Spiritual well-being is one of the aspects that is gaining attention among researchers studying human well-being. Many studies in the past found that the spiritual aspect has a positive relationship and effect on every facet of human life (Fachrunnisa, Adhiatma, \& Tjahjono, 2019; Salman, \& Lee, 2019; Sun et. al., 2016). The importance of the spiritual aspect has also been acknowledged by most researchers who previously conducted studies on human wellbeing, including marital relationship (Khurana \& Joshi, 2017; Beyranvand, Azizi, \& Manshadi, 2016 Dan Khakpour et. al., 2018). Nonetheless, the efforts by WHO to make the spiritual 
aspect the main factor in defining physical, mental, and social health that contributes towards human well-being are still ongoing (Chirico, 2016).

There are various definitions of spirituality put forward by researchers. The definitions of spirituality and religiosity have also always been used interchangeably. However, those two terms do not give the same meaning. Hill and Pargament (2003) suggest that spirituality and religiosity are two important aspects of human life as they are sources of motivation and forces of harmony. It is said to be a way of life that always challenges the human self to constantly seek, gain experience, a source of strength, and as a protector. Moreover, Unruh (1997) has found that spirituality as assessed from literature can be divided into seven main aspects. Those seven aspects are as follows: 1) a relationship with God, spiritual well-being or a power greater than the self, 2) understanding that spirituality does not come from the self but outside of the self, 3) a situation in which the relationship comes from belief in a higher power, 4) an existential qualification that does not originate from the material world, 5) a sense of the meaning and purpose of life, and 6) a combination of the above. Moberg and Brusek (1978) also define spiritual well-being as an aspect that is divided into two main subdimensions. This includes a relationship involving an individual with a more powerful force in a particular type of religious belief and a sense of the meaning and purpose of life. This definition also suggests that the meaning and purpose of this life do not necessarily come from a particular religious structure.

The realization of the importance of studying the spiritual aspect has opened up opportunities for researchers to develop instruments for measuring the aspect of spiritual well-being. Paloutzian and Ellison (1982) have constructed a scale to measure spiritual well-being. This scale is divided into two subdimensions, namely religiosity and existential well-being. Resulting from the construction of this instrument, many studies have been conducted to gather in-depth knowledge on spiritual well-being and various aspects of human life including marital satisfaction.

Although the spiritual aspect is gaining attention among researchers studying marriage, it is still in its infancy. Among the aspects of marital satisfaction that have been studied and linked to the spiritual aspect are studies conducted by Aman, Abbas, Nurunnabi, and Bano (2019) and Kasapoğlu, and Yabanigül (2018). In addition, the aspect of spirituality was also studied to understand sexuality in marriage (Hernandez-Kane, \& Mahoney, 2018), religiosity in marriage (Aman et al., 2019), the relationship between spiritual well-being and marital satisfaction (Rajabi, Alimoradi, \& Moradi, 2017), conflict styles, attendance in religious programs and marital satisfaction (Stinson, Bermúdez, Gale, Lewis, Meyer, \& Templeton, 2017), forgiveness, perception of forgiveness and marital satisfaction over a long period of time (Rose et al., 2018), religiosity, duration of marriage, sexual satisfaction and marital satisfaction (Lazar, 2017), religious commitment and marital satisfaction (Kamomoe, Pinto, \& Selvam, 2017), role of religion in marital satisfaction (Davis et al., 2018), religious commitment, forgiveness and marital satisfaction (Agu \& Nwankwo, 2019), influence of religious commitment, forgiveness, and marital satisfaction (Agu \& Nwankwo, 2019), spiritual intelligence, moral intelligence, marital satisfaction and social networking (Kamalju, Narimani, Atadokht, \& Abolghasami, 2017) and spiritual experience, marital happiness and satisfaction (Avarandeh et al., 2019). 
Although studies linking spiritual aspects and marriage outside Malaysia are increasing, there are still not many studies in Malaysia that focus on spiritual and religious elements in the study of marriage. Many studies on marital satisfaction in Malaysia focus on variables other than spiritual well-being and religiosity. For example, emotional intelligence (Hoesni et al., 2018), general happiness (Hoesni \& Zakaria, 2019), quality of life (Ismail, Azlan \& Yusof 2015), psychological disorders (Wan Azlan et al., 2018), love (Hoesni et al., 2016), demographics, for example, marital status, career and income (Zakaria, Abdul Kadir \& Baharudin 2017), gender (Hoesni et al., 2013), job satisfaction and performance at work (Nasir \& Amin 2010), personality traits and the risk of divorce (Bahareh et al., 2013), anxiety in communicating (Hoesni, Manap, \& Zakaria, 2020) and positive communication in marriage (Hoesni, Manap, $\&$ Zakaria, 2017). As a result, more studies delving into the aspects of spirituality and marriage are needed to understand the psychology of marriage in the Malaysian context.

In addition, studies that focus on spirituality in Malaysia are also not much associated with marriage. While there are studies related to spirituality and religion, however, they are not focused on the aspect of marriage. As an example, the study of spiritual aspects leads to the spiritual well-being of teachers (Hamsyah \& Ahmad 2018), spiritual practices by female cancer patients (Ismail, 2019), social support among adolescents with suicidal ideation (Ibrahim et al., 2019), anxiety about death and meaning in life (Hoesni, Adnan, \& Roshaizad, 2020), deviant behavior among adolescents (Aziz et al., 2020), spirituality in the empowerment of human well-being (Mohamad, Osman, Mokhtar, 2020) and spiritual counseling (Saper et al., 2018).

Hence, realizing the importance of studying spiritual well-being in human life, especially those focuses on marital satisfaction, a study should be conducted in this area. This study aims to identify the relationship between spiritual well-being and marital satisfaction among married Malay individuals in Malaysia.

\section{Research Question}

As a result of the discussion, this study aims to answer the research question as follows.

1. What is the relationship between spiritual well-being and marital satisfaction among married Malay individuals in Malaysia?

\section{Methodology \\ Study design}

This study employs an explorative survey design in the form of a questionnaire. This study is part of wider research in identifying the psychological aspects of marriage.

\section{Sampling}

The selection of samples in this study was conducted by cluster sampling from 10 areas in the Klang Valley, Malaysia. The area is categorized as rapidly developing and densely populated. A total of 578 Malays from Klang Valley (males $=256$, females $=322$ ) who have been married for more than a year participated voluntarily in the study. 


\section{Questionnaire}

The questionnaire in this study is divided into three main sections. Part A consists of questions related to the background of the respondents, Part $B$ consists of questions related to spiritual well-being and Part $C$ consists of questions related to marital satisfaction.

Part A contains questions related to the background of the respondent. It covers related questions such as gender, age, level of education, income, and duration of marriage.

Part B comprises a number of questions covering spiritual well-being using the Spiritual Well Being (SWB) instrument originally developed by Paloutzian and Ellison (1982). Later, it was translated by Syed Sohail Imam, Noor Harun Abdul Karim, Nor Radziah Jusoh and Nor Ehsaniah Mamad (2009) and Ahmad S. Musa (2016). SWB has two subdimensions to measure spiritual well-being, namely religiosity well-being (RWB) and existential well-being (EWB). The total number of items is 20 , with 10 items per subdimension. SWB also contains reverse items to help control items representing a high score of spiritual well-being. RWB refers to an individual's relationship with God in daily life. Some examples of RWB items are as follows, "I believe Allah loves and cares about me", "I have a meaningful personal relationship with Allah" and "I believe Allah cares about my problems". Meanwhile, EWB is a subdimension related to life goals, satisfaction, and relationships with others and the situations around us. Examples of items for EWB are "I don't know who I am, where I came from and where I will go", "I feel this life is a positive experience" and "I am worried about my future". Items in this instrument have been assigned with choices of answers namely $1=$ strongly disagree, $2=$ disagree, $3=$ not sure, $4=$ agree and $5=$ strongly agree. The minimum score is 15 and the maximum score is 75. Scores for the RWB and EWB subdimensions ranged from 10 to 60 . This scale has no midpoint and it uses a 6-point Likert scale. The items in this instrument have been assigned choices of answers namely $1=$ strongly disagree, up to $6=$ strongly agree. The higher the RWB and EWB scores, the higher the RWB and EWB levels. Previous studies reported high test and retest reliability $(r=.73$ to .99$)$, consistent internal reliability $(r=.78$ to .94), construct validity and two-factor scale structure (Ellison \& Smith, 1991). A more complex factor structure was suggested by Ledbetter, Smith, Fischer, Vosler-Hunter, and Chew (1991). Moreover, a cross-cultural evaluation study of this instrument across five continents in 10 languages and 300 studies conclude this instrument is suitable for use (Paloutzian, Agilkaya-Sahin, Bruce, Kvande, Malinakova, Marques, Musa, Nojomi, Öztürki, Putri, \& You, 2021).

Part $\mathbf{C}$ consisted of questions measuring marital satisfaction of married individuals using the ENRICH Marital Satisfaction Scale developed by Fowers and Olson (1993). This instrument has 15 items. 10 marital satisfaction items cover the personality and habits of the couple, how to handle responsibilities in the family, communication, decision making and problem-solving, finances, spending time together, expressions of intimacy and sexuality, parenting, relationships with parents, in-laws and friends and practicing religion and religious values in life. Examples of marital satisfaction items include "I am very satisfied with the way we manage responsibilities and roles in our marriage", "I am dissatisfied with my partner's personality traits and habits" and "I am dissatisfied with our communication and I feel my spouse do not understand me". In addition, there are five ideal distortion items inserted in this scale to help moderate the effects of ideal distortion thinking in marriage. Among the examples of ideal distortion items are "My spouse and I are very understanding of each other", "My spouse and I are very understanding and sympathetic to every mood" and "I have never regretted a relationship with my spouse even for a moment". This scale uses a 5-point 
Likert scale. The items in this instrument are assigned choices of answers namely $1=$ strongly disagree, $2=$ disagree, $3=$ not sure, $4=$ agree and $5=$ strongly agree. The minimum score is 15 and the maximum score is 75 . The higher the score, the higher the marital satisfaction. The scoring method is done according to the manual provided in an article by Fowers and Olson (1993). Previous studies have reported high test and retest reliability (Fowers, \& Olson, 1989; Masoumi, Khani, Kazemi, Kalhori, Ebrahimi, \& Roshanaei, 2017).

\section{Procedure}

Questionnaires were distributed to respondents who voluntarily participated in the study. Completed questionnaires were collected by the enumerators. Then, questionnaires were coded and analyzed to achieve the objectives of the study.

\section{Analysis}

The analysis in this study has been done using IBM Statistical Package for Social Sciences (SPSS) version 23. Descriptive analysis such as mean, percentage, frequency, standard deviation, minimum and maximum values was used to obtain descriptive information of the respondents studied. Besides that, Pearson correlation analysis was used to identify the relationship between spiritual well-being and marital satisfaction.

\section{Study Results}

The results of the study are divided into two main parts. The first part is the results of the descriptive analysis and the second part is the results of the inferential analysis.

\section{The results of descriptive statistical analysis}

The results of the descriptive analysis are explained in terms of mean, percentage, frequency, mean, standard deviation, minimum value, and maximum value. The variables that have been analyzed are the background of the respondents, namely gender, age, level of education, total monthly income, and duration of marriage.

Overall, details of the analysis are described in Table 1 . The respondents involved in this study were 256 males (44.3\%) and 322 females (55.7\%). The age of the respondents in this study was between 20 years to 60 years old with a mean age of 36.81 years old with a standard deviation of 9.35 years old. The majority of the respondents have Sijil Pelajaran Malaysia (SPM) (34.08\%), followed by Sijil Tinggi Pelajaran Malaysia (STPM) or Diploma and Bachelor's degree (32.01\%). The total income of the respondents has a mean (M) of RM3,013.79 with a standard deviation (S.D.) of RM2,016.93. The duration of marriage has a mean (M) of 11.16 years with a standard deviation (S.D.) of 9.65 years. 
Table 1: The results of descriptive analysis on the respondents' background

\begin{tabular}{|c|c|c|c|c|c|c|}
\hline Variables & $\mathbf{N}$ & $\%$ & $\mathbf{M}$ & S.D. & Mean & Max \\
\hline \multicolumn{7}{|l|}{ Sex } \\
\hline Male & 256 & 44.3 & & & & \\
\hline Female & 322 & 55.7 & & & & \\
\hline Age & & & $\begin{array}{l}36.81 \\
\text { years }\end{array}$ & $\begin{array}{c}9.35 \\
\text { years }\end{array}$ & $\begin{array}{c}20 \\
\text { years }\end{array}$ & 60 years \\
\hline \multicolumn{7}{|l|}{$\begin{array}{l}\text { Level of } \\
\text { education }\end{array}$} \\
\hline Primary school & 6 & 1.04 & & & & \\
\hline SRP/PMR & 16 & 2.77 & & & & \\
\hline SPM & 197 & $\begin{array}{c}34.0 \\
8\end{array}$ & & & & \\
\hline STPM/Diploma & 185 & $\begin{array}{c}32.0 \\
1\end{array}$ & & & & \\
\hline $\begin{array}{c}\text { Bachelor's } \\
\text { degree }\end{array}$ & 136 & $\begin{array}{c}23.5 \\
3\end{array}$ & & & & \\
\hline Master's degree & 32 & 5.54 & & & & \\
\hline $\mathrm{PhD}$ & 6 & 1.04 & & & & \\
\hline $\begin{array}{l}\text { Total monthly } \\
\text { income }\end{array}$ & & & $\begin{array}{c}\mathrm{RM} 3,013 . \\
79\end{array}$ & $\begin{array}{c}\mathrm{RM} 2,016 \\
.93\end{array}$ & RM150 & $\begin{array}{c}\mathrm{RM} 15,5 \\
00\end{array}$ \\
\hline $\begin{array}{l}\text { Duration of } \\
\text { marriage }\end{array}$ & & & $\begin{array}{l}11.16 \\
\text { years }\end{array}$ & $\begin{array}{c}9.65 \\
\text { years } \\
\end{array}$ & $\begin{array}{l}0.083 \\
\text { years }\end{array}$ & 39 years \\
\hline TOTAL & $\begin{array}{l}578 \\
\text { indiv } \\
\text { idual } \\
\mathrm{s}\end{array}$ & & & & & \\
\hline
\end{tabular}

\section{Inferential Statistical Analysis}

Pearson correlation test has been used in the inferential analysis to identify the relationship between the variables studied. In general, there is a positive and significant correlation between spiritual well-being and marital satisfaction. Pearson Correlation Analysis showed that there was a small, positive, and significant relationship between spiritual well-being (religiosity) and marital satisfaction ( $r=.19 * *, k<0.01)$. The higher the score for spiritual wellbeing (religiosity), the higher the marital satisfaction score.

In addition, Pearson Correlation analysis also showed that there was a moderate, positive, and significant relationship between spiritual well-being (existential) and marital satisfaction $(r=.32 * *, k<0.01$ ). The higher the respondent's spiritual (existential) well-being score, the higher the score for marital satisfaction. A summary of the results of the analysis is described in Table 2. 
Table 2: The results of Pearson Correlation analysis between spiritual well-being and marital satisfaction.

\begin{tabular}{ccc}
\hline Variables & Items & Marital Satisfaction \\
\hline $\begin{array}{c}\text { Spiritual Well- } \\
\text { being } \\
\text { Religiosity }\end{array}$ & $\begin{array}{c}\text { Correlation } \\
\text { coefficient }(k) \\
\text { Significance level } \\
(r)\end{array}$ & $0.19^{* *}$, \\
Existential & $\begin{array}{c}\text { Correlation } \\
\text { coefficient }(k) \\
\text { Significance level } \\
(r)\end{array}$ & $0.32^{* *}$, \\
\hline
\end{tabular}

\section{Discussion}

The findings of this study show that the element of spiritual well-being is one of the important aspects in understanding the psychological process that takes place in a marriage. Married individuals with high spiritual well-being tend to have higher satisfaction in marriage compared to those with low spiritual well-being. The findings of this study are in line with previous studies in this area (Aman, Abbas, Nurunnabi \& Bano, 2019; Kasapoğlu, \& Yabanigül, 2018 and Hernandez-Kane, \& Mahoney, 2018; Khurana \& Joshi, 2017; Beyranvand, Azizi, \& Dehghan Manshadi, 2016 and Khakpour, Mehrafarid, Akbari Amarghan, Nejat, Fazayeli Yousefabad, \& Toroghi, 2018).

The spiritual well-being aspect in this study is divided into two aspects, namely religiosity wellbeing and existential well-being. The findings of the study show a stronger correlation for the element of spiritual well-being than the existential aspect. This is also parallel with the findings of previous studies. Spiritual (existential) well-being includes matters related to the purpose of having an understanding of the existence of life, satisfaction in life, and relationships between oneself and others as well as situations in life. Moreover, the element of spiritual well-being (religiosity) is a spiritual aspect that has to do with a relationship with God in life. These include self-satisfaction when performing prayers, communicating with God, feeling God is with him or her when alone, feeling God cares about him or her, feeling God helps him or her in everyday life, feeling God loves him or her. The findings of this study are supported by conclusions reached by researchers in other countries who investigated the aspect of marital satisfaction. Previous studies have proven the importance of observing spiritual elements such as religiosity and existentialism in a marriage. Many studies that have been conducted showed that spiritual elements have given a good impact on married life including helping to achieve marital satisfaction, good mental health, and good communication and interaction in a marriage (Moghadam, Chegeni, \& Hafez, 2015; Zaheri, Dolatian, Shariati, Simbar, Ebadi, \& Azghadi, 2016; Wilmoth, Blaney, \& Smith, JR, 2015).

The results of this study also show that the spiritual element is vital in creating a prosperous marriage. It also has an indirect impact on the well-being of the family environment. The need for a spiritual element in marriage is also vital, especially nowadays where people prioritize material and worldly needs rather than focusing on achieving the satisfaction of married life. With the presence of spiritual elements, married individuals seem to have hope, support, and 
guidance through married life besides being dependent on other individuals. This situation is very conducive to building a harmonious society, contributing to the prosperity of an outstanding and eminent country.

\section{Conclusion}

Overall, the element of spiritual well-being is one of the important aspects in increasing marital satisfaction among married individuals. Religiosity and existentialism are two aspects of spiritual well-being that are found to be interrelated and important in helping married individuals to achieve satisfaction in married life. Among the factors that can be taken into account for future research in the field of marriage is a more in-depth investigation of the spiritual aspects in the life of married individuals. Apart from only focusing on quantitative analysis, future studies can also employ a qualitative approach to explore how married individuals utilize the spiritual aspect in improving the well-being of their lives. Qualitative methods can also be used to obtain more diverse and comprehensive data to help married individuals in this era of globalization and competitiveness and the challenging age of technology. In addition, future studies can diversify the samples by including married individuals from various religions and ethnicities. Furthermore, future studies can focus on exploring the spiritual strategies in increasing marital satisfaction used by married individuals from different cultures and beliefs. Thus, studies on marital satisfaction that focus on the element of spiritual well-being need to be expanded further to help married individuals, especially in this era where people are busy in their pursuit of materials, wealth, and prestige.

\section{Contribution}

This research contributes to two main aspects 1) field of psychology and 2) practical aspects dealing with the psychology of married individuals. Firstly, findings in this research helps to expand the knowledge of psychology within marriage focussing on the importance of spirituality. It helps to direct researchers to further investigate spirituality and how it is important increase marital satisfaction among married individuals. Secondly, findings in this study furnish valuable knowledge to helping professions such as counselors, social worker and therapist working with married individuals or couples. Not only that, findings in this study suggest spiritual aspects to be included in helping marriages flourish.

\section{Acknowledgment}

We would like to express our appreciation and gratitude to the Ministry of Education, Malaysia (MOE) for providing the fund from Fundamental Research Grant Scheme (FRGS) to complete this study FRGS/2/2014/SS02/UKM/02/1. Many thanks to those who were, directly and indirectly, involved in completing this study.

\section{References}

Ahmad, S. M. (2016). Factor Structure of the Spiritual Well-Being Scale: Cross-Cultural Comparisons between Jordanian Arab and Malaysian Muslim University Students in Jordan. Journal of Transcultural Nursing, 27(2), 117-125.

Ismail, A. (2019). Spiritual practices of female cancer patients towards well-being in lives. Islamiyyat, 93-97.

Mohamad, A. D., Osman, K., \& Mokhtar, A. I. (2020). Spirituality in maqasid for the empowerment of human well-being. International Journal of Business and Social Science, 69-73. 
Agu, S. A., \& Nwankwo, B. E. (2019). Influence of religious commitment, intentionality in marriage and forgiveness on marital satisfaction among married couples. IFE Psychologia: An International Journal, 27(2), 121-133.

Aman, J., Abbas, J., Nurunnabi, M., \& Bano, S. (2019). The relationship of religiosity and marital satisfaction: The role of religious commitment and practices on marital satisfaction among Pakistani respondents. Behavioral Sciences, 9(3), 30.

Avarandeh, M., Eftkharsadi, Z., Bakhtearpour, S., Hidari, A., \& Askari, P. (2019). The causal relationship spiritual experiences happiness through marital satisfaction. Journal of Psychologicalscience, 18(78), 719-726.

Aziz, S., Nen, S., Hoesni, S. M., \& Manap, J. (2020). Tingkah Laku Devian Dalam Kalangan Remaja Di Semenanjung Malaysia Berdasarkan Faktor Pemantauan lbu Bapa, Komunikasi Ibu Bapa Dan Religiositi. Jurnal Sains Sosial@ Malaysian Journal of Social Sciences, 4(1), 93-101.

Bahareh, Z., Nasir, R., Mastor, K. A., \& Shahrazad, W. (2013). Personality traits, the risk of divorce and marital satisfaction: an intrapersonal model. The Social Science, 8(5), 466472.

Beyranvand, H., Azizi, A., \& Manshadi, D. S. M. (2016). Relationship between attachment styles and spiritual intelligence and marital satisfaction in married female teachers. Journal of Mazandaran University of Medical Sciences, 26(135), 149-152.

Chirico, F. (2016). Spiritual well-being in the 21st century: It's time to review the current WHO's health definition. Journal of Health and Social Sciences, 1(1), 11-16.

Davis, J. M., Horrell, K. E., Anderson, T. L., \& Hall, L. M. E. (2018). Religious and Role Contributions to the Marital Satisfaction of Evangelical Women. Journal of Psychology and Theology, 46(3), 184-198.

Emmons, R. A., \& Paloutzian, R. F. (2003). The psychology of religion. Annual review of psychology, 54(1), 377-402.

Fachrunnisa, O., Adhiatma, A., \& Tjahjono, H. K. (2019). Collective engagement and spiritual wellbeing in knowledge based community: a conceptual model. In Conference on Complex, Intelligent, and Software Intensive Systems (pp. 899-906). Springer, Cham.

Fowers, B. J., \& Olson, D. H. (1989). ENRICH Marital Inventory: A discriminant validity and cross-validation assessment. Journal of marital and family therapy, 15(1), 65-79.

Fowers, B. J., \& Olson, D. H. (1993). ENRICH Marital Satisfaction Scale: A brief research and clinical tool. Journal of Family Psychology, 7(2), 176-185. https://doi.org/10.1037/0893-3200.7.2.176

Hamsyah, H., \& Ahmad, A. (2018). Aktiviti masa senggang dan kesejahteraan spiritual guru. Proceedings International Conference on Social Studies and Humanities (ICOSH 2018)

Hill, P. C., \& Pargament, K. I. (2003). Advances in the conceptualization and measurement of religion and spirituality: Implications for physical and mental health research. American Psychologist, 58(1), 64-74.

Hernandez-Kane, K. M., \& Mahoney, A. (2018). Sex through a sacred lens: Longitudinal effects of sanctification of marital sexuality. Journal of Family Psychology, 32(4), 425.

Hoesni, S. M., Adnan, H. A., \& Roshaizad, N. A. (2020). A preliminary study on the relationship between death anxiety, spiritual well-being and the meaning of life among individuals living in Klang Valley, Malaysia. International Journal of Psychosocial Rehabilitation, 24(4), 4130-4139.

Hoesni, S. M., Manap, J., \& Zakaria, S. M. (2020). Kebimbangan Berkomunikasi Dengan Pasangan Dan Kepuasan Perkahwinan Dalam Kalangan Individu Melayu yang Berkahwin 
di Lembah Klang, Malaysia (Communication Apprehension with Spouse and Marital Satisfaction Among Married Urban Malay Individuals in Klang Valley, Malaysia). Jurnal Psikologi Malaysia, 34(2), 218-226.

Hoesni, S. M., \& Zakaria, S. M. (2019). Marital satisfaction and general happiness among urban Malays in Klang Valley. International Journal of Recent Technology and Engineering, 8(2S10), 97-101.

Hoesni, S. M., Kadir, N. B. Y. A., \& Hafidz, S. W. M. (2018). Kecerdasan Emosi dan Kepuasan Perkahwinan dalam Kalangan Melayu Bandar (Emotional Intelligence and Marital Satisfaction among Urban Malays). Jurnal Psikologi Malaysia, 32(4), 113-122.

Hoesni, S. M., Manap, J., \& Zakaria, E. (2017). Komunikasi Positif Dalam Perkahwinan Orang Melayu Bandar Di Lembah Klang (Positive Communication Among Married Urban Malays In Lembah Klang). e-Bangi, 14(5).

Hoesni, S. M., Abdul Kadir, N. B., Wan Sulaiman, W. S., \& Hafidz, S. W. M. (2016). Love and marital satisfaction among urban Malays: comparing three groups length of marriage. Jurnal Psikologi Malaysia, 32-41.

Hoesni, S. M., Subhi, N., Alavi, K., and Azreena, W. J. (2013). Exploring love and marital satisfaction among married Malay males. Pertanika Journal of Social Science and Humanities, 59-68

Ibrahim, N., Din, N. C., Ahmad, M., Amit, N., Ghazali, S. E., Wahab, S., ... \& Halim, M. R. T. A. (2019). The role of social support and spiritual wellbeing in predicting suicidal ideation among marginalized adolescents in Malaysia. BMC Public Health, 19(4), 553.

Ismail, R., Azlan, H. A. N., \& Yusof, F. (2015). Assessing the Relationship Between Quality of Life and Marital Satisfaction among Malaysian Married Couples. e-BANGI, Journal of Social Sciences and Humanities, 65-71

Kamalju, A., Narimani, M., Atadokht, A., \& Abolghasami, A. (2017). The prediction of affairs based on spiritual intelligence, moral intelligence, marital satisfaction, and use of virtual social networks with moderating role of gender. Journal of Family Counseling \& Psychotherapy, 6(2), 39-67.

Kamomoe, P. K., Pinto, H., \& Selvam, S. (2017). The association between Christian religious commitment and marital satisfaction: A mixed method study among married individuals in Nairobi City County. International Academic Journal of Social Sciences and Education, 1(5), 58-74.

Kasapoğlu, F., \& Yabanigül, A. (2018). Marital satisfaction and life satisfaction: The mediating effect of spirituality. Spiritual Psychology and Counseling, 3(2), 177-195.

Khakpour, M., Mehrafarid, M., Amarghan, A. H., Nejat, H., Yousefabad, F. M., \& Toroghi, R. (2018). Effect of spiritual family therapy on marital satisfaction in couples with husbands' drug-dependent. Journal of Research and Health, 8(4), 365-372.

Khurana, K., \& Joshi, A. (2017). Marital Satisfaction and Spiritual Personality: A Relational Overview. Global Journal of Enterprise Information System, 9(1), 29-35.

Lazar, A. (2017). Moderating effects of religiousness and marriage duration on the relation between sexual and marital satisfaction among Jewish women. Archives of sexual behavior, 46(2), 513-523.

Masoumi, S. Z., Khani, S., Kazemi, F., Kalhori, F., Ebrahimi, R., \& Roshanaei, G. (2017). Effect of marital relationship enrichment program on marital satisfaction, marital intimacy, and sexual satisfaction of infertile couples. International Journal Of Fertility \& Sterility, 11(3), 197. 
Moberg, D. O., \& Brusek, P. M. (1978). Spiritual well-being: A neglected subject in quality of life research. Social Indicators Research, 5, 303-323.

Moghadam, S. R. M., Chegeni, M. E., \& Hafez, A. A. (2015). Explore the relationship among spiritual health, marital satisfaction, and demographic characteristics (age, duration of marriage, duration of employment) in Mafi hospital nurses of Susa city. Journal of Research on Religion \& Health. 1(4), http://journals.sbmu.ac.ir/enjrrh/article/view/15410

Nasir, R., \& Amin, S. M. (2010). Job satisfaction, job performance and marital satisfaction among dual-worker Malay couples. The International Journal of Interdisciplinary Social Sciences.5(3), 299-305

Paloutzian, R. F., \& Ellison, C. W. (1982). Loneliness, spiritual well-being and the quality of life. Loneliness: A sourcebook of current theory, research and therapy, 224-237.

Rajabi, S., Alimoradi, K. H., \& Moradi, N. (2017). The relationship between structurals of spiritual well-being and marital satisfaction with the mediating role of emotional intelligence and self-differentiation, Journal of Psychological Models And Methods, 8(2), 19-47.

Robert, T. (2003). The relationship between spiritual well-being and job satisfaction among adult workers. (Unpublished doctoral dissertation, Missisipi State University, Mississipi).

Rose, A., Anderson, S., Miller, R., Marks, L., Hatch, T., \& Card, N. (2018). Longitudinal Test of Forgiveness and Perceived Forgiveness as Mediators between Religiosity and Marital Satisfaction in Long-Term Marital Relationships. The American Journal of Family Therapy, 46(4), 356-374.

Salman, A., \& Lee, Y. H. (2019). Spiritual practices and effects of spiritual well-being and depression on elders' self-perceived health. Applied Nursing Research, 48, 68-74.

Saper, M. N., Ismail, Z., Hamjah, S. H., \& Said, Z. (2018). Inovasi kaunseling spiritual untuk kesejahteraan insan. Prosiding Antarabangsa Seminar Kaunseling 2018.

Sayin, M., Demir, I. H., \& Füsun, E. K. Ş. İ. (2019). The relationship of marital satisfaction and life satisfaction with spiritual orientation: the mediating role of sacrifice and sensitivity. Spiritual Psychology and Counseling, 4(3), 237-256.

Stinson, M. A., Bermúdez, J. M., Gale, J., Lewis, D., Meyer, A. S., \& Templeton, G. B. (2017). Marital satisfaction, conflict resolution styles, and religious attendance among Latino couples: Using the actor-partner interdependence model. The Family Journal, 25(3), 215-223.

Sun, V., Kim, J. Y., Irish, T. L., Borneman, T., Sidhu, R. K., Klein, L., \& Ferrell, B. (2016). Palliative care and spiritual well-being in lung cancer patients and family caregivers. Psychooncology, 25(12), 1448-1455.

Imam, S. S., Abdul Karim, N. H., Jusoh, N. R., \& Mamad, N. E. (2009). Malay Version Of Spiritual Well-Being Scale: Is Malay Spiritual Well-being Scale a Psychometrically Sound Instrument? The Journal of Behavioral Science, 4(1), 59-69.

Unruh, A. M. (1997). Reflections on Spirituality and occupation: Garden musings and the Himalayan Blue Poppy. Canadian Journal of Occupational Therapy, 64(3), 156-160.

Wan Azlan, W. A., Abdullah, M. F., Ramalingam, M., \& Abd Rahman, F. N. (2019). Anxiety, Depression and marital Satisfaction in Women with Hyperemesis Gravidarum: A Comparative Cross-Sectional Study. 8th World congress on Women's Mental Health. Asia-Pacific Psychiatry DOI: 10.1111/appy.12416 
Wilmoth, J. D., Blaney, A. D., \& Smith, J. R. (2015). Marital Satisfaction, Negative Interaction, and Religiosity: A Comparison of Three Age Groups, Journal of Religion, Spirituality \& Aging, 27(2-3), 222-240, DOI: 10.1080/15528030.2014.997955

Zaheri, F., Dolatian, M., Shariati, M., Simbar, M., Ebadi, A., \& Azghadi, S. B. H. (2016). Effective Factors in Marital Satisfaction in Perspective of Iranian Women and Men: A systematic review. Electron Physician. 8(12): 3369-3377.

Zakaria, S. M., Abdul Kadir, N. B., \& Baharudin, K. H. (2017). Marital status, career and income as indicators of life satisfaction among middle-aged career women in Hulu Langat, Selangor, Malaysia. Populasi,1-15. 